\title{
Annual changes in serum concentrations of prolactin in captive male black bears (Ursus americanus)
}

\author{
T. Tsubota ${ }^{1 *}$, R. A. Nelson ${ }^{2}$, J. D. Thulin ${ }^{3}$, L. Howell ${ }^{1}$ and \\ J. M. Bahr ${ }^{1 \dagger}$ \\ ${ }^{1}$ Department of Animal Sciences, ${ }^{2}$ Carle Foundation, Department of Internal Medicine and \\ ${ }^{3}$ College of Veterinary Medicine, University of Illinois, Urbana, IL, USA
}

\begin{abstract}
Prolactin may be involved in the regulation of reproduction in black bears (Ursus americanus) as it is a mediator of photoperiodic changes in a number of species. The objectives of this study were to validate a radioimmunoassay to measure prolactin in bear serum and to describe seasonal changes in serum prolactin concentrations in captive male bears. Serum samples were obtained nine times during a year from three captive male black bears that were denning between November and March and active during the other months. The heterologous prolactin radioimmunoassay, using pig ${ }^{125} \mathrm{H}$-labelled prolactin and goat anti-pig prolactin as a primary antibody, was validated. Injection of thyrotrophin-releasing hormone into the three male bears in June resulted in a rapid increase in serum concentrations of prolactin $\left(t=0,11.4-14.8 \mathrm{ng} \mathrm{ml}^{-1} ; t=15-30 \mathrm{~min}, 18.4-28.7 \mathrm{ng} \mathrm{ml}^{-1}\right)$. The sensitivity of the assay was $0.08 \mathrm{ng}$ per tube. Intra- and interassay coefficients of variation were $5.5 \%(n=6)$ and $5.7 \%(n=6)$, respectively. Serum concentrations of prolactin changed seasonally, with the lowest concentrations in December (mean $\pm \mathrm{SD}=1.1 \pm 0.1 \mathrm{ng}$ $\left.\mathrm{ml}^{-1}\right)$; this was followed by a gradual increase between January $\left(2.6 \pm 0.6 \mathrm{ng} \mathrm{ml}^{-1}\right)$ and April $\left(6.4 \pm 1.2 \mathrm{ng} \mathrm{ml}^{-1}\right)$ and the highest concentrations in May $\left(17.6 \pm 4.7 \mathrm{ng} \mathrm{ml}^{-1}\right)$, preceding peak testosterone concentrations in June. The observation that prolactin secretion increased with increasing daylength suggests that photoperiod may be an external regulator. The presence of high concentrations of prolactin before peak testosterone concentrations suggests that prolactin may play a role in regulating seasonal changes in the testes.
\end{abstract}

\section{Introduction}

American black bears (Ursus americanus) have a mating season from late spring to early summer (Erickson and Nellor, 1964; Reynolds and Beecham, 1980) and den during the winter season (Nelson et al., 1973). Seasonal changes in serum testosterone and $\mathrm{LH}$ concentrations were reported in male black bears (McMillin et al., 1976; Palmer et al., 1988; Tsubota and Kanagawa, 1989; Horan et al., 1993). Profiles of serum FSH and prolactin have not been reported. Immunocytochemical localization of steroid enzymes in the testes of black bears indicated that spermatogenesis is initiated during the middenning period (January) and is associated with a rise in serum testosterone and oestradiol concentrations. These steroids may be synthesized in Leydig cells and Sertoli cells, respectively (Tsubota et al., 1993). However, it is not known what

\footnotetext{
*Present address: Laboratory of Theriogenology, Faculty of Agriculture, Gifu University, Gifu 501-11, Japan.

${ }^{+}$Correspondence.

Revised manuscript received 5 December 1994.
}

stimulates and maintains the steroid synthesis associated with spermatogenesis in the bear testis.

Prolactin is a pituitary hormone that changes in response to photoperiod. In general, long days increase prolactin concentrations whereas short days decrease secretion (Pelletier, 1973; Lincoln ef al., 1978). Prolactin plays a major role in seasonal changes in reproduction (Curlewis, 1992), pelage moult cycle (Duncan and Goldman, 1984; Smith et al., 1987; Curlewis et al., 1988), growth and metabolism (Eisemann $e$ t al., 1984; Bartness et al., 1987; Curlewis et al, 1988). However, its precise role in male reproduction in some mammalian species is controversial. In sheep, the annual change in prolactin concentration is not causally linked to the seasonal pattern of gonadal activity (Barenton and Pelletier, 1983), whereas increasing prolactin concentrations in spring may be important for reproduction in golden hamsters (Klemcke et al., 1984; Bartke et al., 1984) and blue foxes (Smith et al., 1987).

The objectives of this study were to establish a prolactin assay for bear serum using a porcine prolactin radioimmunoassay and to describe seasonal changes in serum prolactin concentrations in captive male black bears. 


\section{Materials and Methods}

\section{Animals}

Three adult male American black bears, aged 6-8 years, were used in this study. These bears were sexually mature because their testes exhibited full spermatogenesis during the mating season (Tsubota et al., 1993). They were housed in a United States Department of Agriculture (USDA) approved facility, consisting of an outdoor run and denning area. All studies were approved by The Carle Foundation Animal Care and Use Committee. Commercial dog chow (18\% protein, $6 \%$ crude fibre, $6 \%$ crude fat) and water were provided until denning. Bears entered dens around 13 October 1992 and left them on or around 12 March 1993. Bears were subjected to natural photoperiod throughout the year. Water was available throughout denning, but the bears seldom drank.

\section{Blood sampling}

For all studies, bears were first anaesthetized i.m. with Telazol (Elkins-Sinn Inc., Cherry Hill, NJ) at a dose of $5 \mathrm{mg}$ $\mathrm{kg}^{-1}$ body mass, using a metallic poke stick syringe. Telazol contains tiletamine hydrochloride and zolazepam hydrochloride. Blood was sampled from the femoral vein at 15-20 min intervals, when repeated sampling was necessary. Immediately after collection, blood was centrifuged at $1200 \mathrm{~g}$ for $20 \mathrm{~min}$ at $4^{\circ} \mathrm{C}$, and the serum was removed and stored at $-20^{\circ} \mathrm{C}$ until assayed.

\section{Behaviour of bears}

The bears demonstrated the usual behaviour associated with seasonal changes. In summer, food intake was $5000-8000 \mathrm{kcal}$ day ${ }^{-1}$ (Nelson et al., 1983). In autumn, hyperphagia occurred, with food intake approaching $20000 \mathrm{kcal} \mathrm{day}^{-1}$. With the onset of denning, aphagia occurred and persisted throughout the five month period of denning. Bears rarely left their dens to drink water. They were alert when approached and required similar amounts of anaesthetic to active bears. The serum urea:creatinine ratio decreased to values of ten or less, which is indicative of the metabolic adaptation to denning (Nelson et al., 1984).

\section{Prolactin assay}

A heterologous radioimmunoassay using pig ${ }^{125}$ I-labelled prolactin and goat anti-pig prolactin serum as a primary antibody was established. Purified porcine prolactin (USDApPRL-B-I) for iodination and standards and primary antiserum were obtained from D. J. Bolt (USDA Animal Hormone Program). The following procedure was used with modifications: $0.05 \mathrm{~mol}$ phosphate buffer $\mathrm{l}^{-1}, \mathrm{pH} 7.4(25 \mu \mathrm{l})$ was added to the reaction microtube containing pig prolactin $(5 \mu \mathrm{g})$. ${ }^{125} \mathrm{I}-\mathrm{Na}(0.05 \mathrm{mCi}$ ) (Amersham Corporation, Arlington Heights, IL) was added to the tube. The solution was mixed with $0.5 \%$ $(\mathrm{w} / \mathrm{v})$ chloramine-T $(5 \mu \mathrm{l})$ for $60 \mathrm{~s}$ and then $0.1 \%(\mathrm{w} / \mathrm{v})$ sodium metabisulfite $(20 \mu \mathrm{I})$ was added for $2-5 \mathrm{~s}$. After $0.05 \mathrm{~mol}$ phosphate buffer $\mathrm{l}^{-1}(200 \mu \mathrm{l})$ was added to the tube, the contents of the tube were drawn into a $1 \mathrm{ml}$ disposable syringe and placed on a column that contained approximately $0.5 \mathrm{ml}$ anion exchange resin (Bio-Rad-Analytical Grade Anion Exchange Resin AG1-X10, 100-200 mesh). The solution was collected from the column into a tube containing $0.5 \mathrm{ml}$ assay buffer (PBS, containing $1 \%(\mathrm{w} / \mathrm{v}) \mathrm{BSA}, \mathrm{pH}$ 7.4). The binding of the ${ }^{125}$ I-labelled prolactin was checked by reacting 10000 c.p.m. with several different concentrations of the primary antibody. The optimal binding of the primary antibody was approximately $30 \%$ binding.

On the first day, standards and samples $(200 \mu \mathrm{l})$ plus assay buffer $(400 \mu \mathrm{l})$ were incubated with primary antibody $(1: 30000 ; 100 \mu \mathrm{l})$ and ${ }^{125} \mathrm{I}$-labelled prolactin (approximately 10000 c.p.m. in $100 \mu \mathrm{l}$ ) at $4^{\circ} \mathrm{C}$ for $48 \mathrm{~h}$. On the third day, the second antibody (rabbit anti-goat gamma globulin 1:15; Antibodies Incorporated, Davis, CA) and $6 \%$ polyethylene glycol (6000 molecular weight) were added to the tubes and they were centrifuged at $1500 \mathrm{~g}$ at $4^{\circ} \mathrm{C}$ for $30 \mathrm{~min}$. The supernatant was removed by aspiration and the radioactivity of the pellet was measured in a gamma counter. Each sample was assayed in duplicate. Tubes containing normal goat serum instead of primary antibody were treated by the same procedure to determine nonspecific binding. A pooled sample was assayed at two different volumes in each assay. Intra- and interassay coefficients of variation were $5.5 \%(n=6)$ and $5.7 \%(n=6)$, respectively.

\section{Validation of the prolactin assay}

The pig prolactin radioimmunoassay was validated according to the following steps. First, increasing amounts of pooled bear sera and pituitary homogenates were assayed to determine parallelism. The pituitary was obtained from a dead bear, stored at $-80^{\circ} \mathrm{C}$, homogenized using a sonicator and diluted 1:10 before assay. Second, three anaesthetized male black bears were injected i.v. with $7 \mu \mathrm{g}$ thyrotrophin releasing hormone (TRH) $\mathrm{kg}^{-1}$ body mass and blood was sampled before TRH injections and at intervals of 15 min thereafter for $2 \mathrm{~h}$. This experiment was done in June when bears were reproductively active. Sera were stored at $-20^{\circ} \mathrm{C}$ until assayed for prolactin.

\section{Testosterone assay}

Serum concentrations of testosterone were measured by radioimmunoassay as described by Palmer et al. (1988). Double-extraction with anaesthesia grade ether and a mixture of $75 \%(\mathrm{v} / \mathrm{v})$ methanol and hexane was followed by radioimmunoassay. Mean recovery rate after extraction was $83.2 \%$. All samples were corrected for procedural losses. The crossreactivity of the antiserum was reported by Bahr et al. (1983). The testosterone assay for black bear serum was validated by column chromatography, parallelism and recovery of unlabelled ligand (Palmer et al., 1988). The sensitivity of the testosterone assay was $15 \mathrm{pg}$. Intra- and interassay coefficients of variation were $7.7 \%(n=5)$ and $13.3 \%(n=9)$, respectively. Statistical analysis was carried out by Student's $t$ test. 


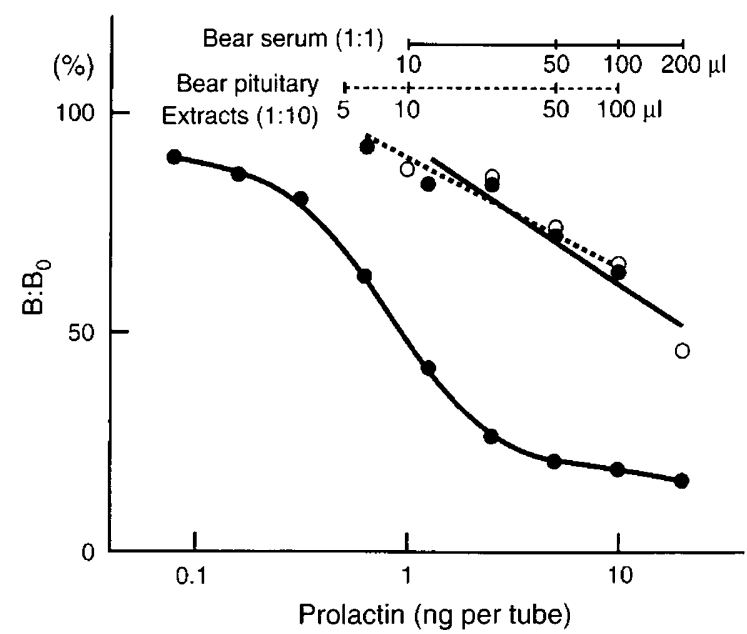

Fig. 1. Standard curve with pig prolactin and different amounts of prolactin in the bear serum and pituitary homogenate for three individual bears. This graph shows the parallelism between the standard curve and increasing amounts of prolactin in the bear serum $(-)$ and pituitary homogenate $(---)$. Parallelism was assessed by regression analysis and comparison of the slopes by $t$ test.

\section{Results}

Validation of the prolactin assay

A plot of values obtained for several dilutions of bear serum $(10-200 \mu \mathrm{l})$ but not for the pituitary homogenate $(0.6-10 \mu \mathrm{l})$ was parallel to the standard curve for pig prolactin (Fig. 1). Intravenous injection of three bears with $7 \mu \mathrm{g} \mathrm{TRH} \mathrm{kg}^{-1}$ body mass caused a significant increase $(P<0.002)$ in serum concentrations of prolactin from $11.4-14.8 \mathrm{ng} \mathrm{ml}^{-1}$ to $18.4-28.7 \mathrm{ng} \mathrm{ml}^{-1}$ within $15-30 \mathrm{~min}$ followed by a gradual decrease (Fig. 2).

\section{Annual changes in serum testosterone and prolactin concentrations}

Serum concentrations of testosterone were low during January (0.4-0.6 $\left.\mathrm{ng} \mathrm{ml}^{-1}\right)$, began to increase in February (bear 1) or March (bears 2 and 3) and peaked in June (12.4-63.2 ng $\mathrm{ml}^{-1}$ ) (Fig. 3). Testosterone concentrations decreased to $0.1-2.0 \mathrm{ng} \mathrm{ml}^{-1}$ in October, and then increased $(P<0.01)$ in December $\left(5.0-7.1 \mathrm{ng} \mathrm{ml}^{-1}\right)$. The lowest concentrations of prolactin (1.0-1.1 ng ml ${ }^{-1}$ ) were measured in December (Fig. 4). Prolactin then increased gradually through February $\left(2.0-2.9 \mathrm{ng} \mathrm{ml}^{-1}\right)$ and March $\left(2.6-3.2 \mathrm{ng} \mathrm{ml}^{-1}\right)$. Serum prolactin concentrations increased further, from $4.3-6.3 \mathrm{ng} \mathrm{ml}^{-1}$ in March to 5.0-7.2 $\mathrm{ng} \mathrm{ml}^{-1}$ in April and to high concentrations $(P<0.02)$ in May $\left(12.4-21.6 \mathrm{ng} \mathrm{ml}^{-1}\right)$ preceding the testosterone peak in June. However, prolactin concentrations decreased again in June $\left(12.2-13.7 \mathrm{ng} \mathrm{ml}^{-1}\right)$. The serum concentrations of prolactin of the three male bears were similar in amounts and in seasonal changes. In contrast, there were greater differences in serum concentrations of testosterone among the three bears; however, the seasonal changes were similar.

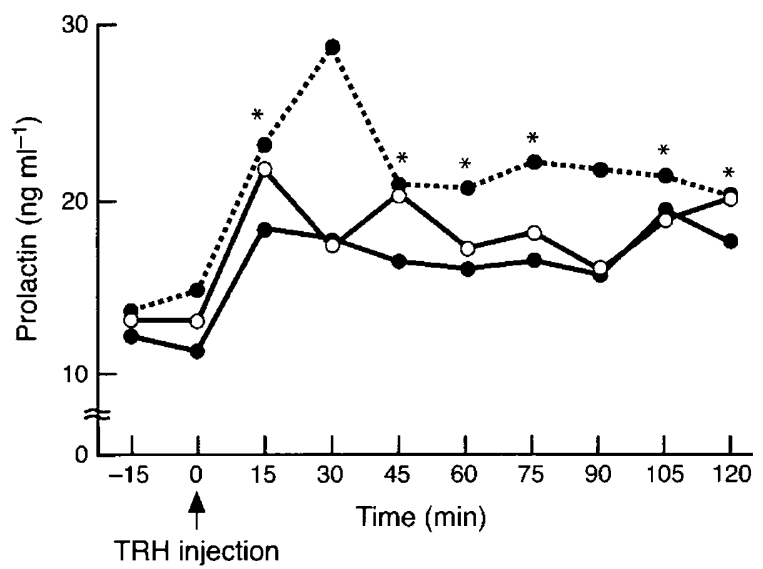

Fig. 2. Changes in serum concentrations of prolactin after i.v. injection of thyrotrophin releasing hormone (TRH) $\left(7 \mu \mathrm{g} \mathrm{kg}{ }^{-1}\right.$ body mass) into three male black bears during the mating season in June. *Averaged prolactin concentrations for the three bears were significantly higher than concentrations at time $O(P<0.05)$.

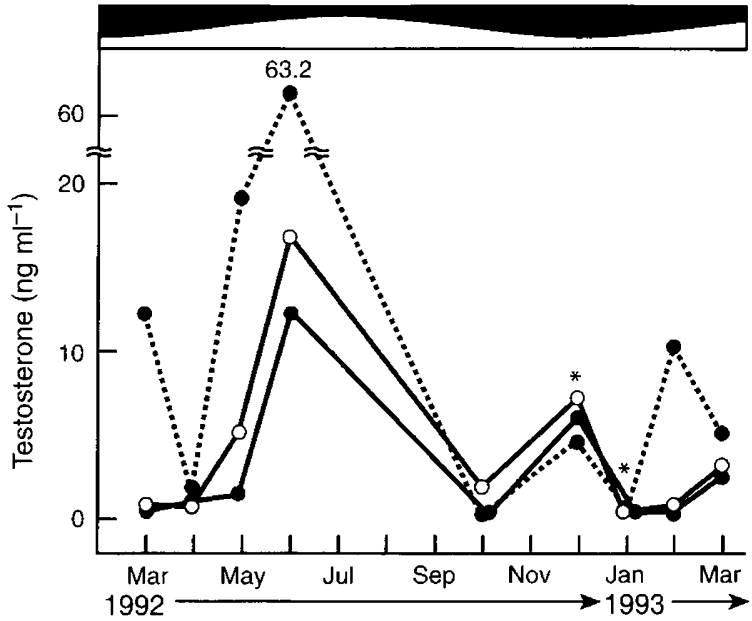

Fig. 3. Annual changes in serum testosterone concentrations in three male black bears. *Significant difference between the average testosterone concentration for the three bears and the subsequent average testosterone concentration $(P<0.05)$. The diagram at the top of the graph indicates the change in daylength with season. Clear area: daylength; black area: darkness.

\section{Discussion}

This is the first known report of serum prolactin measurements in black bears sampled at various times throughout a year; it demonstrates the validation of a pig prolactin radioimmunoassay to measure prolactin concentrations in bears. The prolactin assay was validated by two different methods. First, parallelism between the pig prolactin standard curve and increasing volumes of bear serum and pituitary extracts was found. Second, TRH injection of male bears with complete spermatogenesis (Tsubota et al., 1993) caused a significant increase in prolactin release within 15 to $30 \mathrm{~min}$. Similar increases in serum prolactin concentrations after TRH injection were reported in humans (Bowers et al., 1971), cows and bulls 


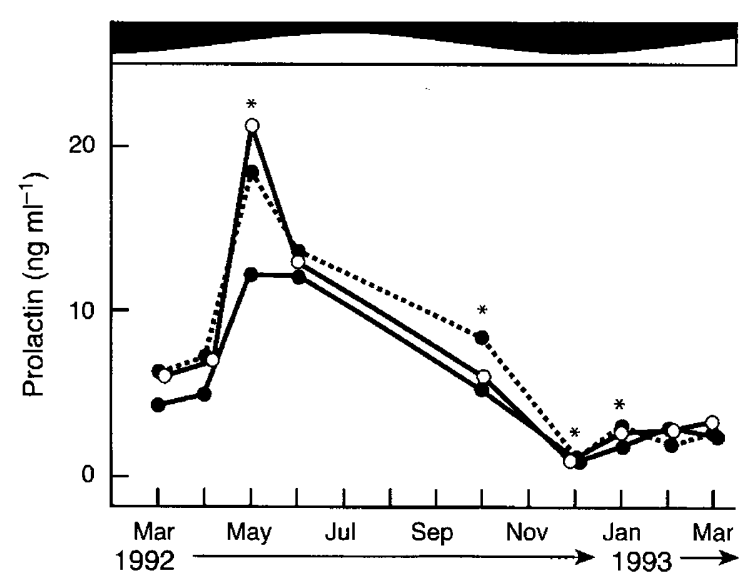

Fig. 4. Annual changes in serum concentrations of prolactin in three male black bears. *Significant difference between the average prolactin concentration for the three bears and the subsequent average prolactin concentration $(P<0.05)$. The diagram at the top of the graph indicates the change in daylength with season. Clear area: daylength; black area: darkness.

(Convey et al., 1973), pigs (Dubreuil et al., 1988; Stuber et al., 1990), domestic dogs (Reimers et al., 1978) and wolves (Kreeger et al., 1991).

This study reports a seasonal change in serum concentrations of prolactin in black bears. Concentrations were lowest in December and increased gradually through February and March, reached peak values in May and then gradually declined. This circannual prolactin rhythm is similar to that of other mammals and appears to be mediated by photoperiod; concentrations decrease with decreasing daylength and increase with increasing daylength, although two bears exhibited a decline of prolactin release in June when daylength was still increasing. This change in prolactin concentrations correlates well with the regression of the bear testis in autumn and winter (Horan et al., 1993) and its gradual recrudescence beginning in January and resulting in full spermatogenesis and steroidogenesis in spring (Tsubota et al, 1993). This seasonal pattern of prolactin secretion and the presence of high serum prolactin concentrations one month before maximum serum testosterone concentrations suggests a role for prolactin in the regulation of seasonal testicular function in black bears.

Prolactin is known to be involved in the regulation of male testicular function. In golden hamsters, it appears to modulate the effects of photoperiod on gonadal function (Bartke et al., 1975). If the golden hamster is used as a model to understand seasonal reproductive activity many possible functions can be suggested for prolactin in black bears. Foremost, it stimulates the activity of the testes of hamsters by increasing the number of LH receptors (Bex and Bartke, 1977). Second, prolactin increases the activity of the steroidogenic enzymes of the testis, $3 \beta$ - and $17 \beta$-hydroxysteroid dehydrogenase (Hafiez et al., 1971; Musto et al., 1972). Third, it promotes the accumulation of testicular esterified cholesterol (Bartke, 1971). In addition, the increase in prolactin concentrations upon exposure to long photoperiods causes a decrease in the negative feedback sensitivity to testosterone (Matt et al., 1984). Each of these physiological changes enhances testicular steroidogenesis, resulting in an active testis and perhaps the annual serum testosterone peak. Localization of both prolactin and LH receptors in bear testes, either by immunocytochemistry or in situ hybridization will further elucidate the role of prolactin in seasonal reproduction of male black bears.

Serum concentrations of testosterone in black and brown bears are highest in spring and lowest in autumn, a few months before denning (McMillin et al., 1976; Palmer et al., 1988; Tsubota and Kanagawa, 1989). While these studies reported the testosterone peak of free ranging bears to be in April or May, testosterone concentrations in the captive bears studied here were highest in June (Horan et al., 1993; Tsubota et al., 1993). In addition, the results of this study showed another testosterone peak in December, although its magnitude was considerably lower than the peak in June. According to morphological and immunocytochemical studies of spermatogenesis and steroidogenic enzymes in bear testes, spermatogenic activity is initiated in January, the mid-denning time (Tsubota et al., 1993). This finding suggests that the small peak in serum testosterone in December is associated with the initiation of spermatogenesis in January. Testosterone has been shown to reinitiate spermatogenesis in adult stalksectioned Rhesus monkeys (Marshall et al., 1983) and hypophysectomized rats (Huang et al., 1987).

In summary, a valid pig prolactin radioimmunoassay for bear serum has been described, seasonal changes in serum prolactin concentrations have been reported, and a second, smaller serum testosterone peak in December has been identified. These results suggest that prolactin plays a regulatory role in testicular recrudescence in black bears. On the basis of evidence from studies of golden hamsters, it is possible that prolactin is required during the latter part of denning to enhance testicular steroidogenesis and to prepare bears for the mating season in June. While the December rise in testosterone concentrations does not correlate with prolactin concentrations, it is possible that this testosterone peak is independently associated with the initiation of spermatogenesis. Further studies will elucidate the roles of both prolactin and testosterone in the regulation of seasonal reproduction in black bears.

The authors thank A. Busch for animal care and acknowledge D. J. Bolt for supplying porcine prolactin from the USDA Animal Hormone Program. This study was supported in part by the Japan Society for the Promotion of Science (T. Tsubota) and the Carle Foundation, Urbana, IL (R. A. Nelson, J. M. Bahr).

\section{References}

Bahr JM, Wang SC, Huang MY and Calvo FO (1983) Steroid concentrations in isolated theca and granulosa layers of preovulatory follicles during the ovulatory cycle of the domestic hen Biology of Reproduction 29 326-334

Barenton B and Pelletier J (1980) PRL, testicular growth and LH receptors in the ram following light and 2-Br- $\alpha$-ergocryptine (CB-154) treatments Biology of Reproduction 22 781-790

Bartke A (1971) Effects of PRL and luteinizing hormone on cholesterol stores in the mouse testis Endocrinology 49 317-324

Bartke A, Croft BT and Dalterio S (1975) PRL restores plasma testosterone levels and stimulates testicular growth in hamsters exposed to short daylength Endocrinology 97 1601-1604

Bartke A, Matt KS, Siler-Khoder TM, Soares MJ, Talamantes F, Goldman BD, Hogan MP and Hebert A (1984) Does PRL modify testosterone feedback in the hamster? Pituitary grafts alter the ability of testosterone to suppress luteinizing hormone and follicle-stimulating hormone release in castrated male hamsters Endocrinology 115 1506-1510 
Bartness TJ, Wade GN and Goldman BD (1987) Are the short-photoperiodinduced decreases in serum PRL responsible for the seasonal changes in energy balance in Syrian and Siberian hamsters? Journal of Experimental Zoology 244 437-454

Bex FJ and Bartke A (1977) Testicular LH binding in the hamster: modification by photoperiod and PRL Endocrinology 110 1223-1226

Bowers CY, Friesen HG, Hwang P, Guyda HJ and Folkers K (1971) PRL and thyrotropin release in man by synthetic pyroglutamyl-histidyl-proliamide Biochemical and Biophysical Research Communication 45 1033-1041

Convey EM, Tucker HA, Smith VG and Zolman J (1973) Bovine PRL, growth hormone, thyroxine and corticoid response to thyrotropin-releasing hormone Endocrinology $92 \quad 471 \sim 476$

Curlewis JD (1992) Seasonal PRL secretion and its role in seasonal reproduction: a review Reproduction Fertility and Development 4 1-23

Curlewis JD, Loudon ASI, Milne OA and McNeilly MS (1988) Effects of chronic long-acting bromocriptine treatment on liveweight, voluntary food intake, coat growth and breeding season in non-pregnant red deer hinds Journal of Endocrinology 119 413-420

Dubreuil P, Pelletier G, Petitclerc D, Lapierre H, Couture Y, Gaudreau P, Morisset J and Brazeau P (1988) Influence of growth-hormone-releasing factor and (or) thyrotropin-releasing factor on somatotropin, PRL, triiodothyronine and thyroxine release in growing pigs Canadian Journal of Animal Sciences 68 699-709

Duncan MJ and Goldman BD (1984) Hormonal regulation of the annual pelage color cycle in the Djungarian hamster, Phodopus sungorus. II. Role of PRL Journal of Animal Science 59 86-94

Eisemann JH, Bauman DE, Hogue DE and Tavis HF (1984) Evaluation of a role for PRL in growth and the photoperiod-induced growth response in sheep Journal of Animal Science 59 86-94

Erickson AW and Nellor JE (1964) Breeding biology of the black bear. In The Black Bear in Michigan pp 5-45 Eds AW Erickson, J Nellor and GA Petrides. Michigan State University Agriculture Experimental Station Research Bulletin 4, East Lansing

Hafiez AA, Philpott JE and Bartke A (1971) The role of PRL in the regulation of testicular function: the effect of PRL and luteinizing hormone on 3B-hydroxysteroid Endocrinology 50 619-623

Horan KT, Nelson RA, Palmer SS and Bahr JM (1993) Seasonal response of the pituitary and testes to gonadotropin-releasing hormone in the black bear (Ursus americanus) Comparative Biochemistry and Physiology 106A 175-I82

Huang HFS, Marshall GR, Rosenberg R and Nieschlag E (1987) Restoration of spermatogenesis by high levels of testosterone in hypophysectomized rats after long term regression Acta Endocrinologica 116 433-444

Klemcke HG, Bartke A and Borer KT (1984) Regulation of testicular PRL and luteinizing hormone receptors in golden hamsters Endocrinology 114 594-603

Kreeger TJ, Seal US, Cohen Y, Plotka EP and Asa CS (1991) Characterization of PRL secretion in gray wolves (Canis lupus) Canadian Journal of Zoology 69 $1366-1374$
Lincoln GA, McNeilly AS and Cameron CL (1978) The effects of a sudden decrease or increase in daylength on PRL secretion in the ram Journal of Reproduction and Fertility $\mathbf{5 2}$ 305-311

McMillin JM, Seal US, Rogers L and Erickson AW (1976) Annual testosterone rhythm in the black bear Biology of Reproduction 15 163-167

Marshall GR, Wickings EJ, Ludecke DK and Nieschag E (1983) Stimulation of spermatogenesis in stalk-sectioned Rhesus monkeys by testosterone alone Journal of Clinical Endocrinology Met 57 152-159

Matt KS, Bartke A, Soares MJ, Talamantes F, Herbert A and Hogan MP (1984) Does PRL modify testosterone feedback in the hamster? Suppression of plasma PRL inhibits photoperiod induced decreases in testosterone feedback sensitivity Endocrinology 115 2098-2103

Musto N, Hafiez AA and Bartke A (1972) PRL increases 17 $\beta$-hydroxysteroid dehydrogenase activity in the testis Endocrinology 91 1106-1108

Nelson RA, Wahner HW, Jones ID, Ellefson RD and Zollman PE (1973) Metabolism of bears before, during and after winter sleep American Journal of Physiology 224 491-496

Nelson RA, Folk GE Jr, Pfeiffer EW, Craighead JJ, Jonkel CJ and Steiger DL (1983) Behavior, biochemistry, and hibernation in black, grizzly, and polar bears International Conference on Bear Research 5 284-290

Nelson RA, Beck TDI and Steiger DL (1984) Ratio of serum urea to serum creatinine in wild black bears Science 226 841-842

Palmer SS, Nelson RA, Ramsay MA, Stirling I and Bahr JM (1988) Annual changes in serum sex steroids in male and female black (Ursus americanus) and polar (Ursus maritimus) bears Biology of Reproduction 38 1044-1050

Pelletier J (1973) Evidence for photoperiodic control of PRL release in rams Journal of Reproduction and Fertility 35 143-147

Reynolds D and Beecham J (1980) Home range activities and reproduction of black bears in west-central Idaho International Conference of Bear Research and Management 4 21-24

Reimers TJ, Phemister RD and Niswender GD (1978) Radioimmunological measurement of follicle stimulating hormone and PRL in the dog Biology of Reproduction 19 673-679

Smith AJ, Mondain-Monval M, Simon P, Andersen Berg K, Clausen OPF, Homfo PO and Scholler $\mathbb{R}$ (1987) Preliminary studies of the effects of bromocriptine on testicular regression and the spring moult in a seasonal breeder, the male blue fox (Alopex lagopus) Journal of Reproduction and Fertility 81 517-524

Stuber DC, Johnson CL, Green CA, McLaren DG, Bahr JM and Easter RA (1990) Effect of dose and route of administration of thyroid releasing hormone (TRH) on the concentration of prolactin (PRL) and thyroxine $\left(\mathrm{T}_{4}\right)$ in cyclic gilts Domestic Animal Endocrinology 7 291-297

Tsubota T and Kanagawa H (1989) Annual changes in serum testosterone levels and spermatogenesis in the Hokkaido brown bear, Ursus arctos yesoensis Journal of Mammalian Society of Japan 14 11-17

Tsubota T, Nitta H, Osawa Y, Mason JI, Miers PG, Thulin JD, Nelson RA and Bahr JM (1993) Seasonal changes in spermatogenesis, the localization of testicular steroidogenic enzymes and serum steroid profiles in black bears Biology of Reproduction Supplement $\mathbf{4 8} 87$ 